\title{
Effect of variant histology presence and squamous differentiation on oncological results and patient's survival after radical cystectomy
}

\author{
Ertugrul Sefik, Serdar Celik, Ismail Basmaci, Serkan Yarımoglu, Ibrahim Halil Bozkurt, \\ Tarık Yonguc, Bulent Gunlusoy \\ Bozyaka Training and Research Hospital, Department of Urology, Izmir, Turkey.
}

\begin{abstract}
Summary Objective: To evaluate the effect of variant histology on pathological and survival findings in patients undergoing radical cystectomy due to muscle invasive bladder cancer.

Materials and methods: Data from 146 patients with radical cystectomy performed due to muscle-invasive urothelial carcinoma between January 2006 to November 2016 at our clinic were investigated. The preoperative and postoperative data of patients with variant histology were compared with nonvariant urothelial carcinoma patients. Then of patients with variant histology only those with squamous differentiation $(S q D)$ were compared with nonvariant urothelial carcinoma patients in terms of preoperative, postoperative and survival data.

Results: Of the 146 patients, 23 had carcinoma with variant histology. Of these, 17 had SqD, 4 had glandular differentiation, 1 patient had plasmocytoid variant and 1 patient had sarcomatoid variant. In patients with variant histology, postoperative $T$ stage and upstaging was higher, with no difference observed in terms of overall and cancer-specific survival compared with nonvariant urothelial cancer patients. SqD patients were observed to have higher postoperative T stage compared to nonvariant urothelial cancer patients, with no significant difference observed in terms of survival.

Conclusions: In cystectomy pathologies, patients with variant histology (especially SqD patients) were observed to have proportionally higher $T$ stage compared to nonvariant urothelial carcinoma; however there were no significant differences for overall survival and cancer-specific survival.
\end{abstract}

KEY WORDS: Bladder cancer; Radical cystectomy; Squamous differentiation; Variant histology; Survival.

Submitted 26 March 2018; Accepted 7 May 2018

\section{INTRODUCTION}

The most common histologic type observed in bladder cancers is urothelial carcinoma. Urothelial carcinoma is known to sometimes display extraordinary characteristics (variants) differentiated from normal morphology (1). The histologic variant differentiation rate for bladder urothelial carcinoma is reported as $7-81 \%$ in radical cystectomy series (2). There are some studies stating that oncologic results and especially survival results are worse for bladder cancers with variant histology $(3,4)$. The most commonly observed among histologic variants of urothelial carcinoma is squamous differentiation (SqD), though other non-SqD variants may be observed (5). There are studies reporting that the survival for non-SqD histologic variants is lower (6).

In our study in patients with radical cystectomy performed due to muscle-invasive bladder cancer, firstly we aimed to assess the effect of the presence of variant histology on oncologic results and survival results, and secondly we aimed to compare oncologic data and survival data between the most commonly observed histologic variant of SqD with nonvariant urothelial carcinoma.

\section{Materials AND METHOdS}

The data belonging to 178 patients with radical cystectomy performed for bladder tumors from January 2006 to November 2016 at our clinic were retrospectively investigated. Patients who undergone radical cystectomy due to high risk non-muscle-invasive bladder, patients with non-urothelial carcinoma pathology and patients who had missed data were excluded from the study. Finally the study included 146 patients who undergone radical cystectomy operation due to muscle-invasive urothelial bladder carcinoma. Pathologic staging of patients was performed according to the 2002 Union for International Cancer Control (UICC) TNM staging system. All patients provided informed consent before the procedure. Before radical cystectomy, patients had preoperative clinical staging with examination, transurethral resection (TUR) and computed tomography.

The age, gender, preoperative data (presence of hydronephrosis, clinical stage and tumor grade and presence of carcinoma in situ (CIS) in TUR pathology data, postoperative data (postoperative $\mathrm{T}$ stage, tumor grade, surgical margin positivity, lymph node metastasis, presence of prostate and urethra invasion and lymphovascular invasion), upstaging and overall and cancer-specific survival data were assessed.

Additionally patients with variant histology on radical cystectomy pathology and the histologic type of this variant were noted. Patients with variant histology observed were called Group 1, with patients with nonvariant histology called Group 2. Patients in Group 1 with SqD were separately assessed. 


\section{Statistical analysis}

Patient data was first compared between Group 1 and Group 2 and then between patients with SqD and Group 2 using the Mann-Whitney $U$ test and the Pearson $X^{2}$ test. The cancer-specific survival and overall survival times in the groups were assessed with the Kaplan-Maier survival analysis. Statistical analysis was completed using the Statistical Package for the Social Sciences (SPSS) Version 20.0 (SPSS, Chicago, Illinois, USA). Data are presented as mean and standard deviation, with statistical analysis calculated on the median values. The analysis results with $p$ value $<0.05$ were accepted as significant.

\section{Results}

There were 13 females and 133 males with radical cystectomy performed due to muscle-invasive bladder cancer. The mean age of all patients was $64.4 \pm 9$ years. The mean follow-up time was $31.7 \pm 31.8$ months.

Table 1.

Preoperative and postoperative patient characteristics and survival results for Group 1 and Group 2.

\begin{tabular}{|c|c|c|c|c|}
\hline & & $\begin{array}{c}\text { Variant } \\
\text { histology (+) } \\
\text { n: } 23\end{array}$ & $\begin{array}{c}\text { Variant } \\
\text { histology (-) } \\
\text { n: } 123\end{array}$ & $\mathbf{P}^{*}$ \\
\hline Age & & $63.7 \pm 10.4$ & $64.5 \pm 8.7$ & 0.119 \\
\hline Gender & $\begin{array}{l}\text { Female } \\
\text { Male }\end{array}$ & $\begin{array}{c}4 \\
19\end{array}$ & $\begin{array}{c}9 \\
114\end{array}$ & 0.136 \\
\hline Preoperative hydronephrosis & $\begin{array}{l}\text { Positive } \\
\text { Negative }\end{array}$ & $\begin{array}{l}11 \\
12\end{array}$ & $\begin{array}{l}40 \\
83\end{array}$ & 0.158 \\
\hline Preoperative T stage & $\begin{array}{l}\text { T2 } \\
\text { T3 }\end{array}$ & $\begin{array}{c}23 \\
0\end{array}$ & $\begin{array}{c}118 \\
5\end{array}$ & 0.325 \\
\hline Preoperative tumor grade & $\begin{array}{l}\text { Grade } 1 \\
\text { Grade } 2 \\
\text { Grade } 3\end{array}$ & $\begin{array}{c}1 \\
1 \\
21\end{array}$ & $\begin{array}{c}0 \\
4 \\
119\end{array}$ & 0.065 \\
\hline CIS & $\begin{array}{l}\text { Positive } \\
\text { Negative }\end{array}$ & $\begin{array}{c}5 \\
18\end{array}$ & $\begin{array}{l}37 \\
83\end{array}$ & 0.380 \\
\hline Postoperative T stage & $\begin{array}{c}\leq \mathrm{T} 1 \\
\mathrm{~T} 2 \\
\mathrm{~T} 3 \\
\mathrm{~T} 4\end{array}$ & $\begin{array}{c}0 \\
10 \\
10 \\
3\end{array}$ & $\begin{array}{l}19 \\
61 \\
17 \\
26\end{array}$ & 0.035 \\
\hline Postoperative tumor grade & $\begin{array}{l}1 \\
2 \\
3\end{array}$ & $\begin{array}{c}1 \\
1 \\
21\end{array}$ & $\begin{array}{c}4 \\
4 \\
104\end{array}$ & 0.967 \\
\hline Surgical margin & $\begin{array}{l}\text { Positive } \\
\text { Negative }\end{array}$ & $\begin{array}{c}3 \\
20\end{array}$ & $\begin{array}{l}25 \\
98\end{array}$ & 0.416 \\
\hline Lymph node metastasis & $\begin{array}{l}\text { Positive } \\
\text { Negative }\end{array}$ & $\begin{array}{c}7 \\
16\end{array}$ & $\begin{array}{l}23 \\
93\end{array}$ & 0.160 \\
\hline Invasion of prostate & $\begin{array}{l}\text { Positive } \\
\text { Negative }\end{array}$ & $\begin{array}{c}2 \\
20\end{array}$ & $\begin{array}{c}15 \\
100\end{array}$ & 0.606 \\
\hline Invasion of urethra & $\begin{array}{l}\text { Positive } \\
\text { Negative }\end{array}$ & $\begin{array}{c}2 \\
21\end{array}$ & $\begin{array}{c}8 \\
108\end{array}$ & 0.760 \\
\hline Lymphovasculer invasion & $\begin{array}{l}\text { Positive } \\
\text { Negative }\end{array}$ & $\begin{array}{c}7 \\
16\end{array}$ & $\begin{array}{c}18 \\
100\end{array}$ & 0.081 \\
\hline Perineural invasion & $\begin{array}{l}\text { Positive } \\
\text { Negative }\end{array}$ & $\begin{array}{c}3 \\
17\end{array}$ & $\begin{array}{c}17 \\
101\end{array}$ & 0.864 \\
\hline Upstaging & $\begin{array}{l}\text { Positive } \\
\text { Negative }\end{array}$ & $\begin{array}{c}14 \\
9\end{array}$ & $\begin{array}{l}45 \\
78\end{array}$ & 0.029 \\
\hline Overall survival & $47.1 \pm 8.6$ & $52.3 \pm 4.70$ & 0.816 & \\
\hline Cancer spesific survival & $52.8 \pm 4.8$ & $64.8 \pm 5.3$ & 0.824 & \\
\hline
\end{tabular}

A total of 23 patients had variant histology; 17 had SqD, 4 had glandular differentiation, 1 patient had plasmocytoid variant and 1 patient had sarcomatoid variant.

The preoperative, postoperative and survival data and comparison between Group $1(\mathrm{n}=23)$ and Group $2(\mathrm{n}=$ 123) are given in Table 1. When the comparison results are investigated, in the preoperative data, age, gender and clinical T stage and TUR pathology tumor grade and CIS presence were similar in Group 1 and Group 2.

In the postoperative data, tumor grade, surgical margin positivity, prostate invasion, urethral invasion and presence of lymphovascular invasion were similar in both groups. However, the postoperative pathologic T stage and pathologic upstaging were significantly higher in Group 1. There were no significant differences observed between the groups in terms of overall and cancer-specific survival.

Data for patients with urothelial carcinoma with the most commonly observed variant histology of SqD along with Group 2 patient data were compared and results are given in Table 2 . Patients with SqD had significantly higher rates of preoperative tumor grade $(p=0.020)$ and postoperative pathologic T stage $(p=0.040)$ compared with Group 2. When survival data were examined, though patients with SqD had lower overall survival (52.3 \pm 4.7 and $49.6 \pm 10.4$ months, respectively) and cancer-specific survival times $(64.7 \pm 5.3$ and $58.4 \pm 10.7$ months, respectively) compared to Group 2, no statistically significant difference was found between the two groups.

\section{Discussion}

In our study, the rate of patients with variant histology on radical cystectomy pathology was $16 \%$, while the SqD rate was $12 \%$. In the literature, different studies show different rates for variant histology, with these rates reported between 7 and $81 \%$ (2).

This large difference in variant histology rates may be explained by not using defined criteria for evaluation. SqD is reported to be most common among observed histologic variants, in fact in our study the rate of SqD among all histologic variants is $74 \%(17 / 23)$. Though $\mathrm{SqD}$ is characterized by histologic intercellular bridges and keratinization, the World Health Organization (WHO) defines it is a urothelial carcinoma variant (7). Among non-urothelial bladder cancers, squamous cell carcinoma and adenocarcinoma are known for their aggressive nature and low survival rates (8). However there is no consensus on the prognostic importance of histologic 
Table 2.

Patient characteristics and survival results of urothelial carcinoma with squamous differentiation and nonvariant urothelial cancer patients.

\begin{tabular}{|c|c|c|c|c|}
\hline & & $\begin{array}{c}\text { Squamous } \\
\text { differantiation } \\
\mathrm{n}: 17\end{array}$ & $\begin{array}{c}\text { Nonvariant } \\
\text { urothelial cancer } \\
\mathrm{n}: 123\end{array}$ & $\mathbf{P}^{*}$ \\
\hline Age & & $66.9 \pm 10$ & $64.5 \pm 8.8$ & 0.219 \\
\hline \multirow[t]{2}{*}{ Gender } & Female & 3 & 9 & 0.154 \\
\hline & Male & 14 & 114 & \\
\hline \multirow[t]{2}{*}{ Preoperative hydronephrosis } & Positive & 7 & 40 & 0.479 \\
\hline & Negative & 10 & 83 & \\
\hline \multirow[t]{2}{*}{ Preoperative T stage } & $\mathrm{T} 2$ & 17 & 118 & 0.397 \\
\hline & T3 & 0 & 5 & \\
\hline \multirow[t]{3}{*}{ Preoperative tumor grade } & Grade 1 & 1 & 0 & 0.020 \\
\hline & Grade 2 & 0 & 4 & \\
\hline & Grade 3 & 16 & 119 & \\
\hline \multirow[t]{2}{*}{ CIS } & Positive & 4 & 37 & 0.538 \\
\hline & Negative & 13 & 83 & \\
\hline \multirow[t]{4}{*}{ Postoperative T stage } & $\leq \mathrm{T} 1$ & 0 & 19 & 0.040 \\
\hline & $\mathrm{T} 2$ & 8 & 61 & \\
\hline & T3 & 6 & 17 & \\
\hline & T4 & 3 & 26 & \\
\hline \multirow[t]{3}{*}{ Postoperative tumor grade } & 1 & 1 & 4 & 0.802 \\
\hline & 2 & 1 & 4 & \\
\hline & 3 & 15 & 104 & \\
\hline \multirow[t]{2}{*}{ Surgical margin } & Positive & 3 & 25 & 0.796 \\
\hline & Negative & 14 & 98 & \\
\hline \multirow[t]{2}{*}{ Lymph node metastasis } & Positive & 4 & 23 & 0.723 \\
\hline & Negative & 13 & 93 & \\
\hline \multirow[t]{2}{*}{ Upstaging } & Positive & 10 & 45 & 0.078 \\
\hline & Negative & 7 & 78 & \\
\hline Overall survival & & $49.6 \pm 10.4$ & $52.3 \pm 4.7$ & 0.626 \\
\hline Cancer specific survival & & $58.4 \pm 10.7$ & $64.7 \pm 5.3$ & 0.743 \\
\hline
\end{tabular}

independent risk factor in terms of prognosis (13).

In the present study, though the preoperative tumor grade and postoperative tumor stage were high among patients with SqD, the overall survival and cancer-specific survival were similar to nonvariant urothelial carcinoma. Our findings support the report of Moschini et al. who assessed 1067 radical cystectomy cases, observing SqD in $10.2 \%$ of patients with no effect of SqD on survival (14).

Our study has some limitations.

The most important of these are that it is a retrospective study and the low number of patients.

\section{Conclusions}

Patients with variant histology on cystectomy pathology were observed to have high $\mathrm{T}$ stage compared to those with nonvariant urothelial cancer; however there were no significant differences in overall survival and cancerspecific survival.

When the most commonly observed histologic variant of SqD is investigated, though there was higher stage disease compared to nonvariant urothelial cancers, there was no effect shown on overall survival and cancer-specific survival. variants of urothelial carcinoma. Studies of variant histologies and their clinical importance are examined, have generally heterogeneous populations and small scale.

A study by Monn et al. observed that generally patients with variant histology have high pathologic T stage.

When subtypes are investigated, while plasmocytoid and micropapillary variants have high mortality, SqD and sarcomatoid variants were identified to have similar survival to nonvariant urothelial carcinoma (9).

In our study, patients with variant histology had higher postoperative pathologic T stage and upstaging rate compared to nonvariant urothelial carcinoma patients, while survival rates were similar in accordance with the literature.

There are studies showing that bladder cancers with variant histology forms are aggressive tumors with high tumor stage and high lymph node metastasis rates (10-12). Xylinas et al. reported that patients with variant histology on radical cystectomy pathology were correlated with high tumor stage, high lymph node metastasis, lymphovascular invasion (LVI) presence, high recurrence risk and increased cancer-specific mortality.

Furthermore, they stated the patients with non-squamous differentiation were the worst prognostic group. In spite of this, they reported that variant histology was not an

\section{REFERENCES}

1. Shah RB, Montgomery JS, Montie JE, Kunju LP. Variant (divergent) histologic differentiation in urothelial carcinoma is underrecognized in community practice: impact of mandatory central pathology review at a large referral hospital. Urol Oncol. 2013; 31:1650-55.

2. Chalasan i V, Chin JL, Izawa JI. Histologic variants of urothelial bladder cancer and nonurothelial histology in bladder cancer. Can Urol Assoc J. 2009; 3(6 Suppl.4):S193-8.

3. Cai T, Tiscione D, Verze P, et al. Concordance and clinical significance of uncommon variants of bladder urothelial carcinoma in transurethral resection and radical cystectomy specimens. Urology. 2014; 84:1141-6.

4. Wasco MJ, Daignault S, Zhang Y, et al. Urothelial carcinoma with divergent histologic differentiation (mixed histologic features) predicts the presence of locally advanced bladder cancer when detected at transurethral resection. Urology. 2007; 70:69-74.

5. Gluck G, Hortopan M, Stanculeanu D, et al. Comparative study of conventional urothelial carcinoma, squamous differentiation carcinoma and pure squamous carcinoma in patients with invasive bladder tumors. J Med Life. 2014; 7:211.

6. Soave A, Schmidt S, Dahlem R, et al. Does the extent of variant histology affect oncological outcomes in patients with urothelial carcinoma of the bladder treated with radical cystectomy? Urol Oncol. 2015; 33:21.e1-21.e9. 
7. Epstein JI, Amin MB, Reuter VR, Mostofi FK. The World Health Organization/International Society of Urological Pathology consensus classification of urothelial (transitional cell) neoplasms of the urinary bladder. Bladder Consensus Conference committee. Am J Surg Pathol. 1998; 22:1435.

8. Rogers CG, Palapattu GS, Shariat SF, et al. Clinical outcomes following radical cystectomy for primary nontransitional cell carcinoma of the bladder compared to transitional cell carcinoma of the bladder. J Urol 2006; 175:2048-53.

9. Monn MF, Kaimakliotis HZ, Pedrosa JA. Contemporary bladder cancer: variant histology may be a significant driver of disease. Urol Oncol. 2015; 33:18.e15-18.e20.

10. Shariat SF, Karakiewicz PI, Palapattu GS, et al. Outcomes of radical cystectom y for transitional cell carcinoma of the bladder: a contemporary series from the Bladder Cancer Research Consortium. J Urol. 2006; 176:2414-22.
11. Stein JP, Lieskovsky G, Cote R, et al. Radical cystectomy in the treatment of invasive bladder cancer:long-term results in 1,054 patients. J Clin Oncol. 2001; 19:666-75.

12. Hautmann RE, dePetriconi RC, Pfeiffer C, Volkmer BG. Radical cystectomy for urothelial carcinoma of the bladder without neoadjuvant or adjuvant therapy: long-term results in 1100 patients. Eur Urol. 2012; 61:1039-47.

13. Xylinas E, Rink M, Robinson BD. Impact of histological variants on oncological outcomes of patients with urothelial carcinoma of the bladder treated with radical cystectomy. Eur J Cancer. 2013; 49:1889-97.

14. Moschini M, Dell'Oglio P, Luciano' $R$, et al. Incidence and effect of variant histology on oncological outcomes in patients with bladder cancer treated with radical cystectomy. Urol Oncol. 2017; 35:335-41.

\section{Correspondence}

Ertugrul Sefik, MD (Corresponding Author)

sefikanamur@yahoo.com

Serdar Celik, MD

Ismail Basmaci, MD

Serkan Yarrmoglu, MD

Ibrahim Halil Bozkurt, MD

Tark Yonguc, MD

Bulent Gunlusoy, MD

Bozyaka Training and Research Hospital, Department of Urology,

Izmir, Turkey 